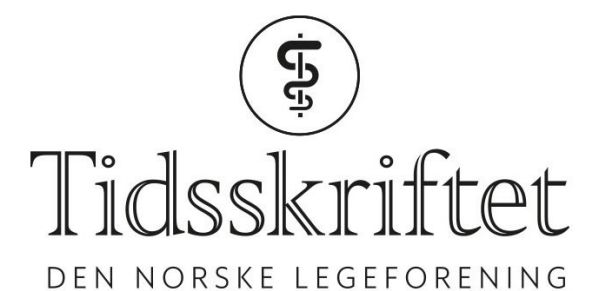

DEN NORSKE LEGEFORENING

\title{
Varicella-zoster-virus - behov for bedre smittevern
}

KRONIKK

\section{PER BJARK}

E-post: bjap@ous-hf.no

Per Bjark (f. 1938) er spesialist i infeksjonssykdommer og rådgiver ved Avdeling for smittevern, Oslo universitetssykehus.

Forfatter har fylt ut ICMJE-skjemaet og oppgir ingen interessekonflikter.

\section{EGIL LINGAAS}

Egil Lingaas (f. 1950) er dr.med., spesialist i medisinsk mikrobiologi og avdelingsoverlege ved Avdeling for smittevern, Oslo universitetssykehus.

Forfatter har fylt ut ICMJE-skjemaet og oppgir ingen interessekonflikter.

Ny kunnskap om varicella-zoster-virusets smittsomhet og sjeldnere kliniske manifestasjoner bør få konsekvenser for smittevern, klinisk diagnostikk og behandling.

Varicella-zoster-virus gir primært varicella (vannkopper). Herpes zoster er en typisk senmanifestasjon med reaktivering av latent virus i sensoriske ganglier. Varicella er en meget smittsom sykdom. Herpes zoster har blitt antatt å være mindre smittsomt, men studier har vist at reaktivering av varicella-zoster-viruset også medfører betydelig virusspredning (1-4). De siste årene har man blitt mer klar over at varicella-zoster-viruset kan forårsake vaskulitter, spesielt i cerebrale arterier (5-9).

Varicella kan forebygges med vaksine, men den inngår ikke i barnevaksinasjonsprogrammet i Norge. Vi antar at dette skyldes skepsis til bruk av levende virusvaksine og usikkerhet rundt langsiktige effekter. Vaksinasjon gir antagelig svakere immunitet enn gjennomgått sykdom, så utbredt vaksinering kan føre til økt forekomst av vannkopper hos ungdom og voksne og mer herpes zoster hos eldre. Kliniske symptomer ved vannkopper kan dempes med aciklovir, men det gjøres sjelden. Profylaktiske tiltak for utvalgte pasientgrupper etter eksponering for varicella-zoster-virus er tidligere omtalt i Tidsskriftet (10).

Antall pasienter med alvorlig svekket immunforsvar og hematologiske og neoplastiske sykdommer $\emptyset$ ker, og stadig flere får immunsuppressive medikamenter. Hos disse er det risiko for alvorligere forløp av varicella-zoster-virusinfeksjon (11). Spørsmålet er om vi tar tilstrekkelig hensyn til dette i diagnostikk og smittevern.

\section{Smitterisiko}

Varicella er svært smittsomt og smitter både gjennom luft og kontakt (10). Lokalisert herpes zoster regnes som mindre smittsomt, men dette kan ha vært undervurdert. 
Et tilfelle av herpes zoster på en sykehusavdeling i USA førte til tre sekundærtilfeller med vannkopper blant pleiepersonalet (1). To av de smittede hadde ikke vært inne i pasientens rom eller vært eksponert for viruset på annen måte. Pasientrommet hadde lett undertrykk, men dør direkte til korridor uten sluse. Kartlegging av luftstrømmer viste livlig luftveksling mellom rommet og korridoren. Forfatterne av studien anbefalte streng isolasjon for alle pasienter med varicella-zoster-virusinfeksjon.

En undersøkelse av 184 pasienter med herpes zoster i Skottland dokumenterte sekundære varicellatilfeller hos nærkontakter til $5,4 \%$ av pasientene (12). En immunsupprimert sykehuspasient med herpes zoster ga i England opphav til 11 tilfeller av vannkopper: fem blant personalet, to medpasienter (hvorav én døde) og fire besøkende (13). Dette understreker betydningen av sterk skjerming rundt immunkompromitterte med herpes zoster, da de antas å ha større virusmengder i sine lesjoner og dermed representere større smittefare.

Tildekking av herpes zoster-lesjoner har betydning for smittefaren. En studie fra Japan viste at vanlig gasbandasje slapp virus lett igjennom, og virus kunne påvises på bandasjeoverflaten og i rommets luftfiltre (2). Dekkende, impermeable hydrokolloidbandasjer ga ikke påviselig spredning på overflate eller i rommet. To av syv herpes zoster-pasienter fikk påvist varicella-zoster-virus-DNA i halsprøve. Forfatterne av studien antok at svelgdeponering av virus ved inhalasjon av partikler fra egen herpes zoster forekommer og at videresmitte fra halsen kan tenkes. Heldekkende, impermeable bandasjer anbefales der dette er anatomisk mulig.

Reaktivering av varicella-zoster-virus i orale slimhinner og dråpesmitte er en annen mulig smittevei. I en studie av 54 pasienter med herpes zoster viste polymerasekjedereaksjonstest (PCR-undersøkelse) at alle var positive for varicella-zoster-virus i saliva tidlig i forløpet, og noen få fortsatt positive etter 15 dager (14). En slik reaktiveringsteori støttes av positiv salivaprøve hos én pasient der man mistenkte en kommende herpes zoster på grunn av smertenes karakter, men som ikke hadde fått synlige lesjoner ennå. Infeksiøst virus ble funnet i vevskultur hos én av to pasienter hvor dette ble forsøkt (14).

Foreldre som har hatt varicella og er seropositive, er noen ganger midlertidige virusbærere i nasopharynxsekret når egne barn har vannkopper (15). Hvilken smitterisiko disse representerer, vet man ikke, men det er aktuelt å vurdere sykmelding om de er helsearbeidere.

\section{Smittevern}

Alle helsearbeidere som er i kontakt med immunsvekkede og infeksjonsutsatte pasienter skulle, ideelt sett, kunne dokumentere seropositivitet for varicella-zoster-virus. Noe slikt krav har man ikke i dag. Mange i disse yrkesgruppene er oppvokst i land der varicella ikke er en like vanlig barnesykdom som hos oss. Helsearbeidere som verken er vaksinert eller har hatt varicella, er potensielt smitteførende i inkubasjonstiden. Sykehusutbrudd forårsaket av personer i inkubasjonsfasen er kjent (16).

I USA anbefaler Centers for Disease Control and Prevention å permittere eller omplassere uvaksinerte, seronegative helsearbeidere fra dag 8 til dag 21 etter eksponering både for varicella og herpes zoster (17). Norge har ikke tilsvarende retningslinjer (18).

Ved herpes zoster anbefaler Folkehelseinstituttets veileder å sette inn infeksjonsforebyggende standardtiltak og kontaktsmitteregime til det er dannet skorper på alt utslett (18). Vi er enig med Folkehelseinstituttet $i$ at pasienter med herpes zoster helst ikke skal ligge i avdelinger med immunkompromitterte pasienter, i så fall bør de ligge i luftsmitteisolat. Veilederen krever ikke direkte enerom for alle herpes zoster-pasienter unntatt i føde- og barselavdelinger (18). Vi mener alle pasienter med herpes zoster bør ha enerom uansett avdeling og utbredelse av utslettet, videre at enerom bør opprettholdes til alle skorper er falt av. I tillegg bør personalet konsekvent bruke munnbind. Påvisning av høye virustall i saliva ved PCR-undersøkelse i tidlig fase av herpes zoster samt forekomst av 
infeksiøst virus dokumentert ved vekst i vevskultur, støtter dette (14).

En del norske sykehus bør antagelig innskjerpe smitteverntiltakene rundt både varicella og herpes zoster. Tiltakene må ikke nødvendigvis være de samme i alle sykehus. Spesiell oppmerksomhet for nosokomial smitte bør man ha i avdelinger som har pasienter med svekket immunforsvar.

\section{Vaksinasjon}

Vi mener at selektiv vaksinering av spesielt utsatte pasientgrupper bør vurderes. Noen aktuelle grupper kan være seronegative personer som skal gjennomgå transplantasjon, pasienter med kroniske sykdommer som juvenil artritt og nyrelidelser, ikke-immune tenåringer og voksne, spesielt kvinner som planlegger graviditet (18).Vaksinasjon av nærkontakter til personer med risiko for alvorlig forløp av varicella er viktig, særlig hvis vaksinen er kontraindisert for pasienten selv.

På utvalgte avdelinger anbefaler Centers for Disease Control and Prevention å kontrollere helsearbeiderne for seropositivitet for varicella-zoster-virus og eventuelt tilby vaksine (17). Vi mener denne praksisen bør vurderes på avdelinger med særlig sårbare pasienter. Her kan man være i en gråsone juridisk, og vi har i Norge ingen hjemmel for tvang.

Verdens helseorganisasjon er klar i sin anbefaling av vaksinasjon hos helsearbeidere som ikke har fått vaksine som barn, ikke har sikker sykehistorie på gjennomgått varicella og som arbeider med sårbare grupper hvor varicella-zoster-virusinfeksjon kan få alvorlig forløp (19). Premature og nyfødte, barn og voksne med immunsvikt, hematologiske og maligne sykdommer samt organtransplanterte er eksempler på noen slike utsatte pasientgrupper.

Fra norsk anestesiologisk hold er det foreslått utbredt vaksinasjon for varicella-zoster-virus hos personer over 64 år for å redusere herpes zoster-forekomst og fremfor alt postherpetisk nevralgi, som er vanskelig å behandle og ofte fører til sterkt nedsatt livskvalitet (20). Dette synspunktet har internasjonal støtte (21). Vaksinen bør trolig ikke være den vanlige, med levende, svekket varicella-zoster-virus, men heller en type beregnet spesielt for nevnte, aldersrelaterte indikasjon (21).

\section{Kompliserende sykdom}

Meningoencefalitt forårsaket av varicella-zoster-virus er velkjent, men ingen hyppig sykdom, og ofte arter det seg klinisk bare som en serøs meningitt (22). Varicella-pneumoni er også velkjent og lett å diagnostisere, men noen ganger krevende å behandle. Sekundære stafylokokk- eller streptokokkinfeksjoner etter varicella kan være alvorlige.

Vårt inntrykk er at klinikere sjelden tenker på mulig varicella-zoster-virusinfeksjon ved cerebrale insulter. Men ettersykdom i form av cerebralt insult etter varicella eller herpes zoster forekommer (5). Forbedret angiografisk diagnostikk og påvisning av virus i spinalvæske dokumenterer varicella-zoster-virusrelaterte cerebrovaskulære hendelser hos pasienter i ulike aldersgrupper $(6,8,23,24)$.

Hos barn er det særlig viktig å vurdere varicella-zoster-virus som årsak til cerebrovaskulære episoder (23). Ikke alle har forutgående typiske symptomer på varicella. Adekvat diagnostikk og rask antiviral behandling er viktig for utfallet.

Varicella-zoster-virus-arteritt bør alltid vurderes ved slagtilfeller de første månedene etter gjennomgått herpes zoster, især etter herpes zoster ophthalmicus (25). En svensk studie antyder at det er økt slagrisiko det første året etter herpes zoster, især hos yngre (26). Hos slike pasienter finner man arteritter med ledsagende stenose eller okklusjon som solitære eller multiple lesjoner i så vel store som små cerebrale arterier. Varicella-zoster-virus-DNA i spinalvæsken påvises hyppigst hos immunkompromitterte pasienter (6). Selv om vi ikke har funnet sammenlignende studier, synes høyt dosert aciklovir intravenøst å være vel indisert (27). Vi mistenker at varicella-zoster-virus-arteritt i sentralnervesystemet er underdiagnostisert og oftest forløper uten kausal terapi. For kjempecellearteritter av typen 
arteritis temporalis er både årsaksfaktorer og behandlingsstrategi ennå noe uklare på grunn av antatt falskt positive immunhistokjemiske funn i noen studier (27-29).

\section{LITTERATUR:}

1. Josephson A, Gombert ME. Airborne transmission of nosocomial varicella from localized zoster. J Infect Dis 1988; 158: 238 - 41. [PubMed][CrossRef]

2. Suzuki K, Yoshikawa T, Tomitaka A et al. Detection of aerosolized varicella-zoster virus DNA in patients with localized herpes zoster. J Infect Dis 2004; 189: 1009 - 12. [PubMed][CrossRef]

3. Lopez AS, Burnett-Hartman A, Nambiar R et al. Transmission of a newly characterized strain of varicella-zoster virus from a patient with herpes zoster in a long-term-care facility, West Virginia, 2004. J Infect Dis 2008; 197: 646 - 53. [PubMed][CrossRef]

4. Cholongitas E, Ilonidis G. Transmission of varicella-zoster virus originating from a patient with localized herpes zoster: Implications for infection control? Am J Infect Control 2010; 38: 669 - 70. [PubMed][CrossRef]

5. Eidelberg D, Sotrel A, Horoupian DS et al. Thrombotic cerebral vasculopathy associated with herpes zoster. Ann Neurol 1986; 19: 7 - 14. [PubMed][CrossRef]

6. Nagel MA, Cohrs RJ, Mahalingam R et al. The varicella zoster virus vasculopathies: clinical, CSF, imaging, and virologic features. Neurology 2008; 70: 853 - 6o. [PubMed][CrossRef]

7. Gilden D, Cohrs RJ, Mahalingam R et al. Varicella zoster virus vasculopathies: diverse clinical manifestations, laboratory features, pathogenesis, and treatment. Lancet Neurol 2009; 8: 731 - 40. [PubMed][CrossRef]

8. Langan SM, Minassian C, Smeeth L et al. Risk of stroke following herpes zoster: a self-controlled caseseries study. Clin Infect Dis 2014; 58:1497-503. [PubMed][CrossRef]

9. Nagel MA, Gilden D. The relationship between herpes zoster and stroke. Curr Neurol Neurosci Rep 2015; 15: 16. [PubMed][CrossRef]

10. Johansen JS, Westergren T, Lingaas E. Profylaktisk behandling etter varicellaeksponering. Tidsskr Nor Legeforen 2011; 131: 1645 - 8. [PubMed][CrossRef]

11. Schmidt SAJ, Kahlert J, Vestergaard M et al. Hospital-based herpes zoster diagnoses in Denmark: rate, patient characteristics, and all-cause mortality. BMC Infect Dis 2016; 16: 99. [PubMed][CrossRef]

12. Seiler HE. A study of herpes zoster particularly in its relationship to chickenpox. J Hyg (Lond) 1949; 47: 253 - 62. [PubMed][CrossRef]

13. Faizallah R, Green HT, Krasner N et al. Outbreak of chickenpox from a patient with immunosuppressed herpes zoster in hospital. Br Med J (Clin Res Ed) 1982; 285: 1022 - 3. [PubMed][CrossRef]

14. Mehta SK, Tyring SK, Gilden DH et al. Varicella-zoster virus in the saliva of patients with herpes zoster. J Infect Dis 2008; 197: 654 - 7. [PubMed][CrossRef]

15. Connelly BL, Stanberry LR, Bernstein DI. Detection of varicella-zoster virus DNA in nasopharyngeal secretions of immune household contacts of varicella. J Infect Dis 1993; 168: 1253 - 5 .

[PubMed][CrossRef]

16. Nassar NT, Touma HC. Brief report: susceptibility of Filipino nurses to the varicella-zoster virus. Infect Control 1986; 7: 71 - 2. [PubMed][CrossRef]

17. Centers for Disease Control and Prevention. Preventing varicella-zoster virus (VCV) transmission from zoster in healthcare settings. http://www.cdc.gov/shingles/hcp/HC-settings.html (10.3.2017).

18. Nasjonalt folkehelseinstitutt. Bruk av isolering av pasienter for å forebygge smittespredning i helseinstitusjoner. http://www.fhi.no/Smittevernveilederen (18.4.2017).

19. WHO. Varicella and herpes zoster vaccines: WHO position paper, June 2014-Recommendations. Vaccine 2016; 34: 198 - 9. [PubMed][CrossRef]

2o. Breivik H. Herpes zoster immunization in older adults has big benefits. J Pain Palliat Care 
Pharmacother 2015; 29:305 - 6. [PubMed][CrossRef]

21. Schmader K. Herpes Zoster. Clin Geriatr Med 2016; 32: 539 - 53. [PubMed][CrossRef]

22. Mogensen TH, Larsen CS. Aseptic meningitis caused by reactivation of varicella-zoster virus in two immunocompetent patients. Scand J Infect Dis 2006; 38: 815 - 8. [PubMed][CrossRef]

23. Amlie-Lefond C, Gilden D. Varicella zoster virus: a common cause of stroke in children and adults. J Stroke Cerebrovasc Dis 2016; 25: 1561 - 9. [PubMed][CrossRef]

24. Borbinha C, Marto JP, Calado S et al. A young woman with ischemic stroke: should we pay more attention to varicella zoster infection? Case Rep Neurol 2016; 8:145 - 50. [PubMed][CrossRef]

25. Schink T, Behr S, Thöne K et al. Risk of stroke after herpes zoster - evidence from a German selfcontrolled case-series study. PLoS One 2016; 11: e0166554. [PubMed][CrossRef]

26. Sundström K, Weibull CE, Söderberg-Löfdal Ket al. Incidence of herpes zoster and associated events including stroke - a population-based cohort study. BMC Infect Dis 2015; 15: 488.

[PubMed][CrossRef]

27. Nagel MA, Gilden D. Developments in varicella zoster virus vasculopathy. Curr Neurol Neurosci Rep 2016; 16: 12. [PubMed][CrossRef]

28. Pisapia DJ, Lavi E. VZV, temporal arteritis, and clinical practice: False positive immunohistochemical detection due to antibody cross-reactivity. Exp Mol Pathol 2016; 100:114 - 5 . [PubMed][CrossRef]

29. Thomas K, Vassilopoulos D. Infections and vasculitis. Curr Opin Rheumatol 2017; 29: 17 - 23.

[PubMed][CrossRef]

Publisert: 16. oktober 2017. Tidsskr Nor Legeforen. DOI: 10.4045/tidsskr.17.0264

Mottatt 3.4.2017, første revisjon innsendt 9.6.2017, godkjent 22.8.2017.

(C) Tidsskrift for Den norske legeforening 2020. Lastet ned fra tidsskriftet.no 